REVISTA DE ESTUDOS EM ARTES CÊNICAS

E-ISSN 2358.6958

\title{
An Actor Prepares e Rabota aktiora nad soboi, Tchast 1: Uma comparação entre o Stanislávski inglês e o russo
}

\author{
Sharon Marie Carnicke
}

Tradução: Felipe Rodrigues Carvalho

\section{Para citar este artigo:}

CARNICKE, Sharon Marie. An Actor Prepares e Rabota aktiora nad soboi, Tchast I: Uma comparação entre o Stanislávski inglês e o russo. Trad. Felipe Rodrigues Carvalho. Urdimento - Revista de Estudos em Artes Cênicas, Florianópolis, v. 3, n. 42, p. 1-28, dez. 2021.

do) DOI: http:/dx.doi.org/10.5965/1414573103422021e0702 


\author{
Sharon Marie Carnicke ${ }^{2}$ \\ Tradução: Felipe Rodrigues Carvalho
}

\begin{abstract}
Resumo
O artigo compara a obra de Konstantin Stanislávski publicada em 1938, Rabota aktiora nad soboi, Tchast I (O trabalho do ator sobre si mesmo, Parte ), com a sua tradução em língua inglesa feita por Elizabeth Reynolds Hapgood e publicada em 1936, An Actor Prepares (Um ator se prepara). A comparação revela importantes diferenças que vão desde o tamanho do texto, o que indica um forte corte editorial, até alterações ou inconstâncias na escolha de determinados termos. Dessa forma, o artigo se debruça sobre as consequências que a tradução em língua inglesa traz para o entendimento do "sistema" no teatro estadunidense, sobretudo no século XX, e como as escolhas feitas pelo conselho editorial e pela tradutora, foram decisivas durante a transmissão e alteração do sentido do texto de Stanislávski e, portanto, de suas ideias.
\end{abstract}

Palavras-chaves: Constantin Stanislávski. Tradução. História do teatro.

An Actor Prepares/ Rabota Aktera Nad Soboľ, Chast' I:
A Comparison of the English with the Russian Stanislavsky

\begin{abstract}
The article compares Konstantin Stanislavski's 1938 book, Rabota aktiora nad soboi, Tchast I (The Actor's Work on Himself, Part ), with Elizabeth Reynolds Hapgood's English translation that was published in 1936, An Actor Prepares. The comparison reveals significant differences ranging from the size of the text, which indicates a strong editorial abridgment, to changes or inconstancies in the choice of certain terminology. Thus, the article focuses on the consequences that this translation brought for the understanding of the "system" in the US theater, especially in the 20th century, and how the choices made by the editorial board and the translator were decisive during the transmission and the change of meaning of Stanislavski's text and, therefore, of his ideas.
\end{abstract}

Keywords: Konstantin Stanislavski. Translation. Theater History.

${ }^{1}$ Artigo publicado em: Carnicke, Sharon Marie. “'An Actor Prepares/Rabota Aktera Nad Soboř, Chast' I': A Comparison of the English with the Russian Stanislavsky." Theatre Journal, vol. 36, no. 4, 1984, p.481494. JSTOR, www.jstor.org/stable/3206736. Acesso em: 18 de fev. de 2021.

2 Professora de teatro e línguas e literaturas eslavas e uma das fundadoras do Centro de Excelência em Ensino da USC. Fluente em russo, ela é a autora internacionalmente aclamada de Stanislavsky in Focus (agora em sua segunda edição), que revela as maneiras significativas nas quais o Método Americano e o Sistema Stanislavsky de treinamento de atores diferem um do outro. As críticas consideram seu livro leitura essencial para atores, diretores e acadêmicos de teatro. PhD, Columbia University (USA).

${ }^{3}$ Bacharel em Artes Cênicas pela Escola de Comunicações e Artes da Universidade de São Paulo (ECA-USP). Ator. Atua também como tradutor para o português de textos e artigos em línguas inglesa e francesa. felipe.r.carvalho96@gmail.com

http://lattes.cnpq.br/7652040518740919 


\section{Resumen}

El artículo compara la obra de 1938 de Konstantín Stanislavski, Rabota aktiora nad soboi, Tchast I (El trabajo del actor sobre sí mismo, Parte ), con su traducción al inglés de Elizabeth Reynolds Hapgood y publicada en 1936, An Actor Prepares (Un actor se prepara). La comparación revela diferencias importantes que van desde el tamaño del texto, lo que indica un fuerte corte editorial, a cambios o inconstancias en la elección de determinados términos. Así, el artículo se centra en las consecuencias que trae la traducción al inglés para la comprensión del "sistema" en el teatro estadounidense, especialmente en el siglo XX, y cómo las elecciones realizadas por el consejo editorial y la traductora fueron determinantes durante la transmisión y alteración del significado del texto de Stanislavski y, por tanto, de sus ideas.

Palabras clave: Konstantín Stanislavski. Traducción. Historia del teatro. 


\section{Nota do Tradutor}

Apenas para fins de contextualização do título do artigo, a autora compara duas versões da mesma obra, a tradução em língua inglesa com o livro original de Stanislávski, em russo. A tradução em questão fora publicada em 1936 sob o título de An Actor Prepares (Um ator se prepara), enquanto a versão russa, ainda que original, foi publicada posteriormente, em 1938, intitulada Rabota aktiora nad soboi, Tchast / (Работа актера над собой: Часть I), ou O trabalho do ator sobre si mesmo, Parte I. Vale dizer ainda que a tradução inglesa em questão corresponde ao primeiro livro de uma série de dois volumes que, em russo, foram publicados em 1938, a parte I e, em 1948, a parte II. A tradução inglesa da segunda parte de Rabota aktiora nad soboi teve publicação em 1949, sob o título de Building a Character (Construindo uma personagem).

*As notas da autora aparecem com a marcação (NA), todos os comentários entre colchetes no corpo do texto são marcações da própria autora. Quaisquer comentários do tradutor aparecerão em notas de rodapé com a marcação (NT).

**Como o artigo trata da problemática das traduções, os títulos das obras de Stanislávski serão referenciados através da língua original da publicação, apenas com uma tradução em nota de rodapé durante cada uma de suas primeiras aparições no texto.

$* * *$ Os termos citados em russo no texto em inglês foram transliterados para o português. No artigo original, onde se lia zadacha, por exemplo, transliteração fonética para o inglês de задачa, escrevemos zadátcha, para facilitar a reprodução da pronúncia original das palavras russas ao leitor lusófono. 


\section{An Actor Prepares e Rabota aktiora nad soboi, Tchast : Uma comparação entre o Stanislávski inglês e o russo}

Chega ao fim uma era do teatro norte-americano moldada, sobretudo, pela descoberta da obra de Stanislávski. Harold Clurman e Lee Strasberg, dois dos três fundadores do Group Theatre faleceram. Stella Adler e Sanford Meisner envelheceram. À essa altura, uma revisão do impacto de Stanislávski faz-se importante, tanto para compreender a história do teatro norte-americano até agora, quanto para prenunciar se a tradição de Stanislávski neste país morrerá com esses grandes professores ou continuará através de discípulos recéminspirados. Tal reavaliação deveria, naturalmente, partir de sua fonte, com os próprios escritos de Stanislávski sobre o processo teatral.

No entanto, seus manuais técnicos para o ator apresentam um imenso problema. Nos Estados Unidos, a maioria daqueles que propagaram a tradição "stanislavskiana" contaram com as versões de seus manuais em língua inglesa para compreendê-la. Aliás, quando eu li pela primeira vez os livros de Stanislávski em russo, ainda como aluna de teatro, fiquei atônita com o quão diferentes eles eram de seus equivalentes em inglês. À primeira vista, seus três manuais parecem ter apenas a metade do volume dos textos russos. Numa leitura mais atenta percebi que os pressupostos que meu professor tinha sobre Stanislávski revelavam-se, geralmente, incorretos pelo texto russo, embora, ironicamente, a versão inglesa fosse usada para dar suporte a eles. Por meio de uma comparação mais detalhada dessas versões, percebi que a lógica de um argumento, às vezes difícil de entender em inglês, era mais clara em russo. A terminologia em inglês é inconsistente se comparada à russa, deste modo chega a ofuscar ou remover as distinções entre dois conceitos parecidos, mas não idênticos. Por fim, as versões em inglês tendem a uma terminologia mais técnica, contribuindo para criar um jargão profissional, ao invés de uma descrição simples e direta do processo do ator. No entanto, a simplicidade na explicação foi o objetivo manifesto de

${ }^{4}$ (NT) Fundado em 1931, em Nova York, por Harold Clurman (1901-1980) e pelos diretores Lee Strasberg (19011982) e Cheryl Crawford (1902-1986), o Group Theatre foi uma companhia de teatro que se propôs a montar peças de relevância social, utilizando-se dos "métodos" de Stanislávski para abordar a verdade em cena. Em 1984, quando este artigo fora publicado, o terceiro dos fundadores, Cheryl Crawford, ainda não havia falecido, tampouco havia os professores e atores Stella Adler (1901-1992) e Sanford Meisner (1905-1997). 
Stanislávski, como ele deixou escrito no prefácio da edição russa de seus manuais: "Em se tratando de arte, deve-se falar e escrever de maneira simples e clara." ${ }^{5}$ De maneira sucinta, ler Stanislávski em inglês é uma experiência muito diferente de lê-lo em russo. Ainda que em russo o texto seja frequentemente prolixo e realmente repetitivo e, embora, esteja repleto dos posicionamentos paternalistas de Stanislávski, o texto é, ao menos, claro e lógico.

O fato de que existem diferenças entre as versões russa e inglesa não permaneceu em segredo, mas, geralmente, essas diferenças foram colocadas de lado como se quase não fossem importantes. A maioria dos críticos simplesmente atribui tais diferenças aos cortes à prosa prolixa de Stanislávski. Por exemplo, em resposta às crescentes atenções dadas à qualidade da tradução, durante os anos 1940, a editora Theatre Arts Books encomendou uma comparação entre An Actor Prepares ${ }^{6}$ e a versão russa. Essa solicitação culminou em uma declaração oficial que alegava que "tudo o que foi cortado consistia em repetições e tautologias." David Magarshack igualmente escreveu que "o principal defeito desta edição norte-americana da grande obra de Stanislávski é que ela omite uma grande parcela do livro original."” A tradutora Elizabeth Hapgood certamente almejou limpar da prosa a sua redundância, em sua introdução a Creating a Hole ela escreveu: "Eu fui encarregada, mais uma vez, à tarefa confiada a mim pelo próprio Stanislávski, de eliminar duplicações e cortar tudo o que não fizesse sentido para atores não russos." Essa intensa alteração editorial foi necessária, ainda que apenas a nível prático: a primeira tradução inglesa fora recusada pela Yale

5 (NA) Constantin Stanislávski. Rabota aktiora nad soboi, Tchast I. Moscou, 1938, p. 14. Joshua Logan sem querer atestou essas diferenças quando disse que "Os livros que Stanislávski escreveu são difíceis de se entender nas traduções inglesas. Sua escrita não é nem de longe tão vívida quanto a sua oratória.” In: Laurence Senelick. Stanislavsky's Double Life in Art. Theatre Survey, v. 22, n. 2, Nov., 1981, p.209.

6 (NT) "Um ator se prepara". Tal versão inglesa foi traduzida para o português como "A preparação do ator", por Pontes de Paula Lima e publicada pela editora Civilização Brasileira. Ver tabela 2 de correlações entre as obras citadas e algumas de suas traduções, em anexo no final do artigo.

${ }^{7}$ (NA) Robert M. MACGregor. Further Entries for a Chronology. In: Erica Munk (org.). Stanislavsky and America. Nova York: Hill and Wang, 1966, p.181; David Magarshack. Introduction. In: Stanislavsky on the Art of the Stage. Boston: Faber \& Faber, 1950, p. 27n.

${ }^{8}$ (NT) "Criando um papel". Tal versão inglesa foi traduzida para o português como "A criação de um papel", por Pontes de Paula Lima e publicada pela editora Civilização Brasileira. Ver tabela 2 de correlações entre as obras citadas e algumas de suas traduções, em anexo no final do artigo.

9 (NA) Elizabeth Reynolds Hapgood. Nota da tradutora. In: Constantin Stanislávski. Creating a Hole. Nova York: Theatre Arts Books, 1961, p.IX. 
University Press por “não ser comercial, sobretudo por conta das repetições" e, então, a Theatre Arts Books a aceitou, com a condição de que novos cortes fossem feitos. ${ }^{10}$

Apesar das explicações convencionais que afirmam que a versão em inglês é apenas menos redundante, as diferenças nas duas versões publicadas afetaram profundamente o entendimento norte-americano sobre Stanislávski. Atores, diretores e professores que moldaram a tradição stanislavskiana neste país raramente tiveram acesso aos textos russos. Esse estudo examinará detalhadamente algumas das principais diferenças entre essas versões e sugerirá como elas comprometem uma compreensão clara do sistema. Acredito que, sem tal análise, seja impossível uma reavaliação da posição que Stanislávski ocupa no teatro norte-americano e, por sua vez, não pode ser feita uma consideração objetiva dos grandes professores de teatro estadunidenses.

No entanto, antes de iniciar minha análise dessas diferenças, talvez seja apropriado um breve olhar sobre a história de como tais consideráveis disparidades aconteceram. ${ }^{11}$ Três aspectos estiveram implicados; primeiro, a maneira com a qual a obra de Stanislávski foi introduzida no teatro norteamericano serviu para pré-estabelecer o que se esperaria de seus livros quando eles, de fato, aparecessem. Desenvolveu-se um misticismo ao redor do Teatro de Arte de Moscou (TAM), originado pelas primeiras resenhas e pelos relatos de testemunhas que sustentavam que o sistema de Stanislávski continha a chave para o segredo do teatro. Essa mística foi intensificada pelas turnês de 1923 e 1924 do TAM, nos Estados Unidos. ${ }^{12}$ Desse modo, os atores estadunidenses foram instigados a buscar e a empregar o que quer que pudessem aprender da técnica, mesmo que a obtivessem de segunda mão. O Group Theatre, com sua fundação em 1931, tentou incorporar, pela primeira vez de forma sistemática, a técnica

${ }^{10}$ (NA) Jean Benedetti. Stanislavski: An Introduction. Nova York: Theatre Arts Books, 1982. p.77.

${ }^{11}$ (NA) Eu dediquei um tratamento mais aprofundado dessa história em um artigo intitulado "The Curious Publication History of Stanislavsky's Books" na Conference of the American Association of Teachers of Slavic and East European Language, Nova York, 30 de dez. de 1983.

12 (NA) Christine Edwards. The Stanislavsky Heritage: Its Contribution to the Russian and American Theatre. Nova York: New York University Press, 1965, p.214; para um interessante conjunto de resenhas sobre as turnês do TAM ver, Victor Emeljanow (org.). Chekhov: The Critical Heritage. Boston: Routledge \& Kegan Paul, 1981, p. 234. 
An Actor Prepares e Rabota aktiora nad soboi, Tchast I: Uma comparação entre o Stanislávski inglês e o russo Sharon Marie Carnicke | Tradução: Felipe Rodrigues Carvalho

desenvolvida por Stanislávski. Naquele momento, contudo, Stanislávski só havia escrito My Life in Art' ${ }^{3}$ e um rascunho não publicado de um manual técnico. ${ }^{14} \mathrm{O}$ primeiro apenas esboçava o sistema, o segundo estava indisponível. As anotações de Michael Tchékhov e o diário de Evguêni Vakhtángov foram traduzidas para seus usos próprios. E, ainda que recorresse aos alunos e atores do MAT que haviam emigrado aos Estados Unidos (Richard Boleslavski, Maria Ouspenskaya e Michael Tchékhov, por exemplo), o Group Theatre tinha poucos elos diretos com Stanislávski, em si. ${ }^{15}$

Stella Adler havia estudado diretamente com o mestre, é claro. Insatisfeita com o trabalho de Strasberg no Group Theatre ela viajou a Paris para se encontrar com Stanislávski, em 1934, apenas quatro anos antes da morte dele. ${ }^{16}$ As teorias dele haviam mudado à época, de acordo com inúmeros de seus discípulos, ele estava no processo de desenvolver um método para ações físicas, que sugere que a vida emocional de uma personagem resulta mais diretamente do comportamento físico do ator, do que da memória emocional. ${ }^{17,} 18$ Assim, tendo sido diretamente adquirido, o conhecimento que Adler trouxe de volta só causou

13 (NT) "Minha vida na arte”. Há uma tradução em língua portuguesa, feita a partir da primeira versão original russa por Paulo Bezerra e publicada pela editora Civilização Brasileira. Ver tabela 2 de correlações entre as obras citadas e algumas de suas traduções, em anexo no final do artigo.

14 (NA) O rascunho datilografado está localizado na Biblioteca de Bancroft, na Universidade da Califórnia, em Berkeley. Ao invés de simplesmente um esboço de um manual técnico para o ator, o texto também analisa três diferentes tipos de teatro: o teatro do espetáculo (nessa categoria ele inclui os teatros comerciais), o teatro de ofício (onde ele situa o sistema de estrelas, ou estrelato) e o teatro da perejivánie ("vivendo através" do papel ou "experiência"). Ele localiza o TAM na terceira categoria. O documento datilografado não contém um livro completo, mas, na verdade, os princípios de um livro.

15 (NA) In: Edwards, 1965, p. 245; Harold Clurman. The Fervent Years. Nova York: Hill \& Wang, 1957, p.86; até Stanislávski menciona Boleslavski como o principal proponente do seu sistema nos Estados Unidos. Ver, Irina Vinográdskaia. Jizn' i tvortchestva K. S. Stanislavskogo: Lietopis'. Moscou, 1973, v. 4, p.368.

16 (NA) Clurman, 1957, p. 129-31; Vinográdskaia, 1973, v. 5, p. 368. Em uma carta a Nemiróvitch-Dántchenko, datada de 8 de agosto de 1930, In: Konstantin Stanislávski. Sobránie Sotchinéni. Moscou, 1961, v. 8, p. 267, Stanislávski menciona um precedente à visita de Stella Adler: "Há não muito tempo atrás, eu me desafiei para ver se eu ainda conseguia trabalhar com atores. Uma atriz do Theatre Guild em Nova York veio me ver e eu trabalhei com ela diariamente, por meia hora, durante duas semanas. No começo eu estava muito cansado, mas então me acostumei com isso." O editor dessas cartas nos conta na nota 545n. que a atriz era Beatrice Wood. Mais tarde durante o mesmo ano, Eunice Stoddard, também do Theatre Guild e mais tarde membra do Group Theatre, fez o mesmo. Essas sessões, no entanto, atraíram muito menos atenção e exerceram menos influência nos palcos estadunidenses do que as sessões de Adler.

(Todas as traduções das cartas de Stanislávski são de nossa autoria).

17 (NA) Vassíli Toporkov. K. S. Stanislávski na repetítsi, Moscou, 1950; e Stanislavski in Rehearsal: The Final Years, trad. Christine Edwards, Nova York: Theatre Arts Books, 1979

18 (NT) A obra em questão, de Vassíli Osipovitch Toporkov, foi traduzida e publicada em português por Diego Moschkovich sob o título "Stanislávski ensaia: memórias". 
mais confusão ao entendimento de Stanislávski no teatro norte-americano. Tendo em vista que Strasberg aprendeu muito através de atores cujo treinamento refletia as formulações iniciais do sistema, ele enfatizava as primeiras questões de Stanislávski: memória emocional e improvisação. Visto que Adler conheceu Stanislávski em sua vida tardia, ela regressou com o último enfoque dele sobre o mapeamento de ações. Essa diferença entre os focos de Strasberg e Adler, como bem se sabe, causou uma ruptura irreparável entre eles e, também, uma ruptura no teatro norte-americano. Em seu conjunto, os trabalhos de Strasberg e Adler, um refletindo um Stanislávski jovem e o outro um Stanislávski tardio, parecem representar uma cisão nas cambiantes ideias do mestre. ${ }^{19}$

Dadas essas condições, pode-se facilmente entender o alvoroço causado pela publicação de An Actor Prepares, em 1936. Profissionais do teatro, que haviam buscado avidamente pelas regras do Sistema de Stanislávski, sob uma escassez de material e uma atmosfera carregada de divergência, esperavam ansiosamente pelo manual do próprio Stanislávski. No entanto, esse público disponível também estava condicionado, através de seus estudos independentes, a esperar certas coisas em relação ao livro. As expectativas mais decisivas, como aquelas elaboradas pelo Group Theatre, naturalmente influenciariam uma tradução, caso a tradutora fosse receptiva ao vocabulário profissional do público leitor e, certamente, Elizabeth Reynolds Hapgood consultou uma variedade de atores estadunidenses ao trabalhar com An Actor Prepares. ${ }^{20}$ O que, em parte, pode explicar as diferenças nas terminologias e na ênfase encontradas entre as versões inglesa e russa. De fato, grande parte da versão inglesa destaca a vida emocional do ator em detrimento do treinamento físico e, portanto, tende a confirmar o entendimento que o Group Theatre tem do sistema.

Em segundo lugar, a situação do TAM à época da primeira turnê nos Estados Unidos e as necessidades financeiras pessoais de Stanislávski criaram as condições que o levaram a publicar seus dois primeiros livros, My Life in Art e An

19 (NA) Benedetti também sugere isto quando escreve: "Fora da Rússia as ideias de Stanislávski veem frequentemente sendo mal compreendidas. Há razões históricas para isso. Originalmente elas eram trazidas ao Ocidente por atores que haviam trabalhado seja no TAM seja em um dos Estúdios e tinham experiência com o Sistema na prática. A questão é quando eles foram ensinados e sobre qual palco do desenvolvimento do Sistema," p.72.

20 (NA) Macgregor, 1966, p.180 
Actor Prepares, não em russo, mas primeiro em inglês, uma língua que ele mesmo não falava. ${ }^{21-22}$ Stanislávski sentiu que a partir de 1923 o crescimento artístico do teatro havia quase acabado. Ironicamente, enquanto os artistas encontravam a sua plateia mais entusiasta, Stanislávski sentiu que esses sucessos se restringiam apenas às descobertas do passado e não estavam construindo nada de novo sobre aquela fundação. Ele também sentia que os atores mais jovens haviam perdido seu ímpeto para explorar e estavam muito acomodados com a aceitação daquilo que já havia se tornado um tipo de dogma sobre sua arte. Ele deixou isso claro em uma carta ao seu codiretor, Vladimir Nemiróvitch-Dántchenko, enviada a Moscou, de Nova York, na metade de fevereiro de 1923: "Devemos nos acostumar à ideia de que não há mais Teatro de Arte. Você, com certeza, entendeu isso antes do que eu. Todos esses anos eu fiquei me enganando em esperanças e resguardando as sobras decadentes. Durante nossas viagens, isso ficou cada vez mais claro, mais evidente, definitivamente. Ninguém possui uma reflexão, ideia, nenhuma grande meta e, sem isso, um empreendimento baseado em ideias não pode sobreviver."23 A comunidade teatral russa e, particularmente, a vanguarda concordavam com essa avaliação do TAM. Na verdade, na época da Revolução Russa, muitos já consideravam o TAM um teatro antiquado e obsoleto. O entusiasmo e excitação com o qual o TAM foi recebido nos Estados Unidos deve ter sido particularmente gratificante para Stanislávski. Assim ele descreveu a noite de estreia da turnê de 1923 à sua esposa: "Nós nunca, nem ao menos uma vez, tivemos tanto sucesso, nem em Moscou, nem em outras cidades. Aqui eles dizem que não se trata de um sucesso, mas de uma descoberta." ${ }^{4}$ Essa sensação de se ter "descoberto" o teatro

${ }^{21}$ (NA) Para consulta, as primeiras publicações dos livros técnicos em inglês são: Constantin Stanislávski. An Actor Prepares, trad. Elizabeth Reynolds Hapgood (Nova York: Theatre Arts Books, 1936); Building a Character, trad. Elizabeth Reynolds Hapgood (Nova York: Theatre Arts Books, 1949) e Creating a Role, trad. Elizabeth Reynolds Hapgood (Nova York: Theatre Arts Books, 1961).

As datas das primeiras publicações desses livros em russo são: Konstantin Stanislávski, Rabota aktiora nad soboi, Tchast / e Tchast /I (Moscou, 1938) e Rabota aktiora nad rol'iu (Moscou, 1957).

As datas das primeiras publicações de My Life in Art são: STANISLÁVSKI, Constantin. My Life in Art, trad. J. J. Robbins (Boston: Little, Brown \& Co., 1924); Konstantin Stanislávski, Moiá Jizn’ v Iskússtve (Moscou, 1925).

22 (NT) A versão russa de Minha vida na arte foi publicada em 1926 e não em 1925 como consta na nota de rodapé acima da autora. In: Elena Vássina; Labaki Aimar. Stanislávski: vida, obra e sistema. 1. ed. Rio de Janeiro: Funarte, 2016, p.326.

${ }^{23}$ (NA) Stanislávski, carta a Nemiróvitch-Dántchenko, meados de fevereiro de 1923. Carta 37, Sobránie Sotchinéni, 1961, v. VIII, p.41.

24 (NA) Stanislávski, carta a M. P. Lilina, fim de dezembro de 1922 a janeiro de 1923, Carta 35, Sobránie Sotchinéni, 1961, v. VIII, p.39. 
nos Estados Unidos ajudou Stanislávski a acreditar que ele havia encontrado um novo lar para dar uma revitalizada continuidade ao trabalho do TAM. Em suas correspondências "esopianas" a Dántchenko, ele até sugere que talvez o TAM deva considerar uma realocação: "Aquele, que esteve nos Estados Unidos e sentiu essa vastidão sem limites, aquele que viu as filas infinitas de pessoas todos os dias na bilheteria... e essas filas não acabam... aquele, que ouviu as vozes e convites das províncias, de centenas de cidades com milhões de pessoas e muitas delas são russas - ele entenderá que nós só podemos seguir em frente com nosso empreendimento nos Estados Unidos." 25 Assim, os Estados Unidos tornaram-se um local natural para se considerar produzir um livro. O público leitor parecia estar garantido e as ideias cairiam sobre novos e entusiasmados ouvidos.

Publicar nos Estados Unidos seria financeira e, também, legalmente lucrativo. Nesse sentido, Stanislávski revelou seu afiado senso para os negócios. A base comercial específica do teatro norte-americano e a forte campanha publicitária montada pelo empresário da turnê, Morris Gest, pareciam garantir o sucesso financeiro do qual Stanislávski tanto necessitava. ${ }^{26}$ Não bastassem as despesas das turnês do TAM pela Europa e pelos Estados Unidos terem sido significativas, seu filho ainda havia contraído tuberculose e precisou morar na Suíça, durante vários anos, para o tratamento. Conforme Stanislávski escreveu, em 1923, “[...] isso custa uma terrível quantidade de dinheiro." ${ }^{27}$ Além disso, esse gasto poderia ser mais bem custeado com uma moeda estrangeira, não russa, uma vez que o valor do rublo havia despencado a quase nada no mercado internacional, após a revolução. O adiantamento inicial pelas vendas do livro, embora modesto, poderia ajudar a pagar despesas urgentes e a lei de direitos autorais dos Estados Unidos, juntamente com a lei de direitos autorais internacional, asseguraria que todos os futuros royalties continuariam a ir para a sua família, algo que a lei Soviética não

\footnotetext{
25 (NA) Stanislávski, carta a Nemiróvitch-Dántchenko, Carta 43: Michael Heim (Universidade da Califórnia, Los Angeles) me sugeriu essa interpretação em um comitê intitulado "Stanislávski e o Teatro de Arte de Moscou". Conference of the American Association of Teachers of Slavic and East European Languages, Nova York, 30 de dezembro de 1983.

${ }^{26}$ (NA) Aliás, Senelick acreditava que "My Life in Art, indubitavelmente, surgiu como um complemento à campanha publicitária” encabeçada por Gest. In: Senelick, 1981, p.201.

27 (NA) Stanislávski, carta a V. S. Aleksandr e Z. S. Sokolova, 15 de setembro de 1923, Carta 45, Sobránie Sotchinéni, 1961, v. VIII, p. 60; ver também Aleksandr Koiransky, Carta a Fred Harris, 17 de novembro de 1960, na Biblioteca de Bancroft, Universidade da Califórnia, Berkeley.
} 
podia garantir. ${ }^{28}$ Logo, Stanislávski deliberadamente planejou publicar nos Estados Unidos.

No entanto, tal decisão contribuiu para gerar discrepâncias na vindoura publicação russa, da mesma forma que certamente as expectativas do público leitor estavam suscetíveis a afetar as traduções. Os textos russos deveriam diferir o suficiente para evitar acusações de pirataria. Após a publicação inicial de My Life in Art, em 1924, Stanislávski escreveu que o livro "não pode ser publicado na Rússia a partir da versão norte-americana. Agora eu tenho que reescrever praticamente tudo de novo." 29 Tal comentário é, com certeza, ambíguo tendo em vista a proporção com a qual Stanislávski queria revisar o texto, era politicamente exigido que o revisasse e, tendo em vista ainda, que fora obrigado pela lei de direitos autorais dos Estados Unidos. Tais considerações devem ter influenciado todos os seus livros.

Em terceiro lugar, a aversão de Stanislávski pela escrita o levou a depender totalmente dos editores de seus livros para concluir as obras. Por isso, as versões em inglês e em russo refletem em parte as decisões, gostos e tendências de seus respectivos editores. Conforme Jean Benedetti devidamente definiu o problema, estudiosos estão "diante de duas versões da mesma obra, baseadas em dois cenários de decisões editoriais distintos, ambos os quais parecem, numa ocasião ou noutra, ter tido a aprovação de Stanislavski." 30

Devido à sua compulsiva necessidade de revisar e aperfeiçoar seu sistema, Stanislávski sentia-se obrigado a alterar, expandir e revisar seus escritos constantemente. Incapaz de concluir seus textos, ele buscou delegar a terceiros a responsabilidade em finalizá-los. O final de My Life in Art é um caso divertido, Stanislávski ficou "em pânico" quando os editores ameaçaram abandonar o projeto se ele não conseguisse entregar o manuscrito completo em duas semanas, sobretudo porque ele já havia gastado o pagamento adiantado. Como explica seu

28 (NA) Vinográdskaia, 1973, v. III, p. 372-373; Senelick, 1981, p.202-204.

29 (NA) Stanislavski, carta a L. A. Leonídov, 24 de março de 1925, cópia datilografada, Muzei, MKhAT, Arkhiv K. S. Stanislávski em Sobránie Sotchinéni, 1961, v. VIII, p. 504; para uma história completa da gênese de My Life in Art e uma comparação detalhada das edições inglesa e russa, ver Senelick, 1981, p.201-211.

30 (NA) Benedetti, p.79. 
amigo Koiransky: "Eu me sentei e, então, dali, escrevi a única passagem com a qual contribuí no livro, aquela que começa com 'Não há arte que não exija virtuosidade [...]'. Nela eu citei Degas. Quando eu a li a Stanislávski ele perguntou - Quem é Degas? - e adicionou as últimas linhas que encerram o livro. Naquela noite nós jantamos na casa de Michel Fokine. O anfitrião perguntou a Stanislávski como seu livro estava se saindo, Stanislávski me olhou descontente através da mesa e disse - Bom, Koiransky diz que ele está pronto." ${ }^{31}$

As mesmas tendências no seu modo de escrita, revisão constante e dependência do trabalho de edição de terceiros, intensificaram-se quando ele começou a trabalhar em seus livros técnicos. A incapacidade de Stanislávski falar exatamente aquilo que ele queria dizer e sua consequente frustração podem ser identificadas na correspondência com a sua editora russa Liubov lákovlevna Gurévitch. Declarações como as seguintes, tiradas de uma carta entre 23 e 24 de dezembro de 1930, testemunham sua confusão e a crescente dependência nela enquanto editora: “Eu não consigo organizar minha enorme quantidade de material e estou me atulhando nele. [...]. Você está com receio de alterar minha imagem. Mas a lástima é que nem eu mesmo conheço minha própria faceta. [.... Prometame que você acreditará em mim quando eu disser que não tenho absolutamente nenhuma ambição literária. Você pode me dizer tudo, você pode fazer o que quiser com os meus textos. O que eu devo fazer, quando me achar obrigado a transferir o que eu não conseguir dar conta. À cada comentário - sou grato; à cada alteração - the agradeço. Faça o que quiser com o livro." 32

A necessidade de uma forte ajuda editorial também ditou a relação que desenvolveram com Stanislávski, Elizabeth Reynolds Hapgood e seu marido, o notório jornalista e crítico, Norman Hapgood. O próprio Stanislávski admitiu essa relação editorial nessa mesma carta à sua editora russa: "[Norman] Hapgood

\footnotetext{
${ }^{31}$ (NA) Koiransky, p. 3, Aleksandr Aleksandrovich Koiransky, crítico e poeta que emigrou aos EUA pouco depois da revolução. Ele havia feito resenhas sobre as produções do TAM, na Rússia, e conheceu Stanislávski quando este chegou aos Estados Unidos, em 1923, Lhe oferecendo seus serviços como intérprete e guia. Ver Senelick, 1981, p.203-204.

32 (NA) Stanislávski, carta a L. la. Gurévitch, 23 a 24 de dezembro de 1930, Carta 222, Sobránie Sotchinéni, 1961, v. VIII, p. 271-278. Liubov lákovlevna Gurévitch foi a diretora e editora chefe de uma das principais revistas Simbolistas russas, Severnyi vestnik. Com o fim da revista, ela trabalhou como crítica literária, especializada em literatura ocidental. Envolveu-se com o TAM e com Stanislávski, em 1907, dali em diante ela estudou e escreveu sobre teatro. Ver seu artigo autobiográfico, “Istoria Severnogo vestnika”, Russkaia literatura XX veka, (ed.) S. A. Vengerov. Munique: Wilhem Fink Verlag, 1972, p. 235-263, sobretudo p.263.
} 
primeiro me auxiliou com seu lápis vermelho. Com seu exemplo em mente, eu também comecei a riscar mais e o livro ficou com a aparência que tem hoje."33 Stanislávski eventualmente deu os direitos norte-americanos sobre todos os seus escritos à Elizabeth Hapgood. ${ }^{34}$

Os meios pelos quais o Sistema foi introduzido nos Estados Unidos, a situação artística do TAM, a situação financeira pessoal de Stanislávski, a base comercial da publicação norte-americana, as contínuas revisões e o estilo prolixo de Stanislávski e as inserções individuais dos editores criaram um conjunto de textos extremamente intrincado, todos os quais devem ser encarados como, de certa forma, "provisórios". ${ }^{35}$ Com os livros publicados é quase impossível estabelecer um texto canônico. Se forem consideradas as datas das primeiras publicações, as traduções em inglês dos dois primeiros livros possuem maior autoridade. Contudo, essas versões oferecem problemas tanto na linguagem quanto no conteúdo editorial. Caso as edições russas sejam usadas como base de estudo, o trabalho é duas vezes mais volumoso, mais preciso na terminologia e no desenvolvimento lógico dos argumentos, porém, uma vez mais, Stanislávski não teve controle completo do projeto editorial.

No entanto, como sugeri acima, a veracidade acadêmica dessa situação não nega o fato prático de que os livros em inglês, da forma como foram publicados, na realidade, influenciaram o teatro norte-americano. Sendo assim, uma comparação das duas versões é apropriada, apesar da confusão textual. Na realidade, justamente por conta dessas dificuldades textuais, um olhar sobre como ambas as versões variam é útil a qualquer um tentando destrinçar as ideias de Stanislávski das de seus intérpretes e, também, àqueles tentando analisar isoladamente o impacto da tradição russa e o impacto do teatro norte-americano.

Ao lidar com as diferenças específicas entre as versões, decidi me concentrar nos textos em inglês e russo tal qual foram publicados, ignorando as possíveis

33 (NA) Stanislávski, carta a L. la. Gurévitch, p. 274. Norman Hapgood havia sido editor chefe das revistas Collier's Weekly, Harper's Weekly e da The International Magazine; ele foi crítico de teatro de jornais de Nova York e do The Bookman. Suas resenhas foram coletadas no livro The Stage in America (Nova York: MacMillan Co., 1901). Ver Macgregor, 1966, p.179.

${ }^{34}$ (NA) Edwards, 1965, p.249.

35 (NA) Benedetti, 1982, p. XI, 58. 
variações do manuscrito, presumindo que os atores e diretores mais diretamente influenciados pelo Sistema tiveram, de modo geral, acesso apenas aos livros. Além disso, tomo os textos russos como linha de base para a comparação porque eles possuem mais, e não menos, rascunhos e contínuas revisões de Stanislavski, e apresentam a terminologia de atores na sua língua materna. Para as partes em que proponho traduções alternativas, consultei atores de treinamento soviético que emigraram aos Estados Unidos. ${ }^{36}$ Por último, minha análise envolverá apenas o primeiro dos livros técnicos de Stanislávski, uma vez que este foi o único cujas provas gráficas inglesas ele pôde ver e o único que ele realmente considerou terminado antes do seu falecimento. ${ }^{37}$ Em inglês, o livro apareceu como An Actor Prepares, em 1936. Em russo, ele apareceu dois anos depois como a Parte I de Rabota aktiora nad soboi.38

A diferença mais marcante entre os dois volumes é, como mencionei antes, o tamanho de cada um. Enquanto o volume russo tem 575 páginas, no inglês somam-se 295 páginas de fonte tipográfica muito maior. Mesmo levando em conta a variação na sintaxe, o tamanho das palavras, a impressão e considerando-se as revisões constantes do próprio Stanislávski, esses números sugerem a diferença de abordagem entre as edições dos dois livros. Basicamente, a edição inglesa consegue essa alteração de tamanho juntando passagens que são semelhantes. O que o Stanislávski vê como dois ou três dias de trabalho de um ator no diário russo, muitas vezes aparece como o trabalho de um dia, condensando o processo que fora cuidadosamente concebido em etapas. Dessa forma, o treinamento aparenta ser menos demorado e, de certa forma, mais simples, em inglês. Além disso, o texto inglês, geralmente, preserva as passagens mais teóricas e suprime exemplos com aplicação prática. Ou seja, o texto inglês parece ser mais um livro teórico, enquanto o russo deva melhor ser denominado como um manual.

De modo geral a condensação e excessiva edição fazem com que o texto

${ }^{36}$ (NA) Meus agradecimentos especiais, quanto a isso, são a Albert Makhtsier, atual professor no Estúdio de Stella Adler e a Edward Rozinsky, atualmente à Universidade de Miami, ambos os quais foram treinados no Instituto Teatral de Leningrado e, por fim, a Dmitry Mikhailov, que estudou no Instituto Teatral de Moscou.

${ }^{37}$ (NA) Stanislávski, Sobránie Sotchinéni, 1961, v. III, p.18.

38 (NA) As edições, inglesa, An Actor Prepares e russa, Rabota aktiora nad soboi: Tchast I, usadas nesta comparação estão indicadas na nota de rodapé no 21, acima. Todas as referências de páginas dessas edições aparecerão entre parênteses no texto. 
inglês aparente ser um resumo do russo, favorecendo, portanto, a opinião tradicional de que a versão inglesa simplesmente elimina repetições. Tal redução expressa tanto a preferência de Hapgood quanto a pressão feita pela editora estadunidense, conforme mencionado anteriormente. No entanto, quando se observa mais especificamente aquilo que está faltando, começamos a perceber que certa perda de clareza seja decorrente dessa redução. Embora a prosa particular de Stanislávski seja florida e repetitiva, a prosa em inglês por vezes parece incoerente ou enigmática devido à aparente exclusão de uma passagem inteira. Semelhante interrupção na lógica pode ser identificada na discussão sobre como o "objetivo" de um ator corresponde à sua "ação".

No texto russo Stanislávski claramente esboça um processo lógico para cada segmento da peça: o ator primeiramente examina as "circunstâncias dadas" a fim de delinear a situação da sua personagem. A situação instaura um "problema" (zadátcha ${ }^{39}$, "objetivo" na tradução de Hapgood) o qual sua personagem deve resolver através da escolha de uma "ação". A "ação" é destinada para inverter a situação a favor da personagem e, com isso, solucionar o problema. Em suma, ao cuidadosamente definir o "problema", o ator lentamente encontra o caminho para sua "ação". ${ }^{40}$ Por meio dessas etapas lógicas, o ator encontra uma ação específica para cada segmento da peça, ao qual pode dar uma completa atenção. Stanislávski, então, enfatiza que a vida emocional da personagem acompanha o resultado natural e direto da ação. Ao focar exclusivamente na ação, o ator sente a vida emocional da personagem. Stanislávski conclui: "Quanto ao resultado, este dará conta de si mesmo quando todo precedente for devidamente executado". Ele termina a passagem alertando que os atores normalmente cometem um erro quando se preocupam com o resultado, em vez das ações (versão russa, p.244-

39 (NT) Zadátcha (задача): “tarefa” ou "problema”. In: Reinaldo Guarino. Dicionário bilíngue Português-Russo. 1. ed. São Paulo: Pomnite Books, 2019.

40 (NA) Cada pequeno segmento possui seu próprio zadátcha (ou "problema") o qual sugere uma "ação". Analogamente, a peça, enquanto um todo possui, um problema predominante ou sverkhzadátcha [сверхзадача] (traduzido por Hapgood como "super-objetivo") o qual se relaciona com todos os problemas menores na peça e que, por sua vez, sugere uma ação preponderante que se interliga com todas as ações individuais de cada segmento. Stanislávski chama essa ação maior de skvoznoe deistvie [сквозное действие] (melhor traduzida como "a linha direta da ação"). Essa ação maior ajuda a focar a relação entre todas as ações menores da peça e a dar foco ao ator conforme ele atravessa a peça. Ver Stanislávski, Rabota aktiora nad soboi, Tchast I, 1938, cap. XV, p.332-346. 
Na passagem em questão do texto inglês, lê-se: "O objetivo será a luz que revelará o caminho certo," explicou o diretor. "O erro que a maioria dos atores cometem é que eles pensam no resultado ao invés da ação que deve prepará-lo..." (p.110). A passagem russa de duas páginas citada acima foi praticamente toda eliminada e o argumento salta inexplicavelmente da definição de "objetivo" (zadátcha ou "problema") para a conclusão, sem uma explicação de como o objetivo é "o caminho" até a "ação" em si. Esse equívoco, por sinal, é uma má e comum interpretação norte-americana do texto e, como demostrarei mais adiante, um equívoco reiterado ao longo da versão inglesa. Em suma, o lógico processo gradual descrito em russo foi desorganizado na versão inglesa.

Mesmo quando a sequência de parágrafos permanece intacta, a eliminação de uma palavra aqui e acolá pode sutilmente afetar o sentindo de uma passagem. Pode-se observar como ocorrem quebras de sentindo ao comparar algumas frases específicas de uma primeira discussão sobre perejivánie ${ }^{41}$, termo traduzido por Hapgood como "a arte de viver um papel" e mais comumente traduzido como "experiência". ${ }^{42,} 43$ A frase russa de Stanislávski "a expressão exterior da experiência interna" em inglês aparece como "a dependência do corpo à alma." Se na passagem onde o texto russo define o trabalho do ator como "a verdadeira expressão dos resultados do trabalho emocional criativo sob uma forma exterior

${ }^{41}$ (NT) Para mais informações sobre a complexidade e pluralidade semântica do conceito de perejivánie (переживание), sugerimos a leitura da tese de doutorado de Michele Zaltron, sobretudo em seu capítulo As Noções de Perejivánie e de Voploschénie: "A perejivánie consiste em uma noção fundamental para o entendimento da investigação de Stanislávski sobre a arte do ator. Em geral, foi traduzida por vivência, revivescência, experiência, emoção. Embora, especialmente em seu emprego na vida cotidiana, possa ainda ser traduzida por aflição ou preocupação. A perejivánie pode ser tanto alegre e prazerosa, quanto triste e capaz de provocar sofrimento. [...] o processo de perejivánie abrange a relação de cada um de nós com o seu entorno, com o mundo, sendo parte inseparável da própria existência humana." In: Michele Zaltron. Stanislávski e o trabalho do ator sobre si mesmo. 1. ed. São Paulo: CLAPS; Perspectiva, 2021, p.33-34.

${ }^{42}$ (NA) Perejivánie pode também ser traduzida como o calco linguístico inglês, "living through", como faz Korainsky em sua carta citada acima, n. 18. Apesar de "living through" não ser uma tradução elegante provavelmente é a mais precisa, pois com perejivánie Stanislávski refere-se à experiência de se viver através das ações da personagem em cena, como se fosse a primeira vez. Ele atesta a centralidade desse conceito em seu sistema quando classifica o trabalho do TAM como o teatro da perejivánie no seu manuscrito anterior, n. 7.

${ }^{43}$ (NT) "Live through" é um verbo frasal, ou expressão idiomática segundo alguns dicionários, que geralmente tem o sentido de "sobreviver", "enfrentar", "suportar" alguma experiência ou situação adversa. No entanto, a construção pode ser interpretada numa acepção hiperbólica, já que a preposição through ("por", "através de") junto com o verbo to live ("viver") permitem a noção de "atravessar" algo ao viver aquilo, isto é, "passar por". Em uma tradução literal, living through é "viver através de", isto é, "experienciar", tendo assim enfoque em "vivenciar" algo por meio da inexorável experiência de vivê-lo. 
de encarnação física", na versão inglesa o trabalho do ator é "reproduzir os resultados do trabalho criativo de suas emoções com precisão.". "Criar a vida humana do espírito do papel" vira, em inglês, simplesmente "criar a vida de um espírito humano." Onde Stanislávski escreve que esse trabalho interno sobre as emoções ajuda o ator a expressar "todas as evasivas nuances e a total profundidade da vida interior do papel," Hapgood traduz que tal arte "pode reproduzir artisticamente os impalpáveis sombreamentos e as profundezas da vida" (versão russa, p.51; versão inglesa, p.15-16). Em cada um desses casos, a versão inglesa enfatiza sutilmente mais o trabalho emocional que o físico e utiliza um tom de voz mais filosófico do que pragmático. A explícita substituição de "encarnação física" por "precisão" demonstra um desvio rumo ao emocional e afastando-se do físico. Do mesmo modo, em duas das frases acima, a palavra "papel" é removida, ignorando, portanto, a preocupação de Stanislávski com as especificidades do texto dramático. Nesse sentido, a versão inglesa enfatiza o trabalho do ator sobre a peça, mesmo que de maneira sutil. Frases como "corpo e alma" e "as profundezas da vida" claramente corroboram para estabelecer o tom mais filosófico.

É claro que Hapgood não tem a intenção de alterar a estrutura teórica. Ela cuidadosamente inclui a frase: "Um ator tem a obrigação de viver intimamente seu papel e, então, dar à sua experiência uma corporificação exterior" (versão inglesa, p. 15). De fato, as mudanças refletem uma tentativa genuína de tornar menos esquisita a tradução literal da obra russa, no entanto, nessa passagem específica, o refinamento aparentemente distorceu o equilíbrio entre os trabalhos interior e exterior do ator. A expectativa do público leitor deve ter contribuído, para tal refinamento. Sem dúvida o trabalho do Group Theatre refletiu um enfoque parecido no âmbito interior em detrimento do exterior.

Até a alteração do título russo, An Actor's Work on Himself, Part ${ }^{44}$, para An Actor Prepares suavemente reforça essa ênfase no trabalho interior do ator, diante da materialização exterior do papel. O título russo sugere que o livro contém apenas os primeiros passos para um treinamento completo do ator, a preparação do seu instrumento e, em seguida, ainda nos conta que o livro é o primeiro de uma

${ }^{44}$ (NT) "O trabalho de um ator sobre si mesmo, Parte I". 
série. O título inglês, por outro lado, é autossuficiente, sugerindo que o seu conteúdo corresponde ao sistema inteiro. Sendo assim, o foco no ator isolado da Parte I de An Actor's Work on Himself aparenta conter a totalidade da técnica, na versão inglesa. É claro que esse título independente funcionou a nível prático, uma vez que o livro foi lançado separadamente e não como parte de uma série. Se, por um lado, a segunda parte de An Actor's Work on Himself foi publicada em russo junto com a primeira parte, em 1938, a tradução da Parte II, intitulada Building a

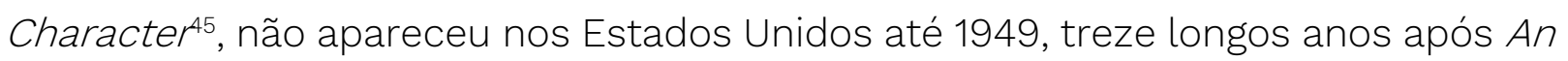
Actor Prepares. Ou seja, nos Estados Unidos, por pelo menos treze anos, o trabalho interior do ator pareceu ser a totalidade do sistema de Stanislávski. ${ }^{46}$

Se a variação dos editoriais é o primeiro ponto de comparação entre An Actor Prepares e An Actor's Work on Himself, o segundo ponto é a escolha e o uso da terminologia. Em seu prefácio à primeira edição russa, Stanislávski discute a natureza da linguagem necessária para descrever o trabalho de ator. Ele alega que a sua terminologia fora inventada por seus alunos, provando com isso que ela é uma consequência natural do próprio trabalho e não um vocabulário prédeterminado e imposto à força, de fora. Ele acrescenta que essas palavras em sua maioria não têm "raízes científicas", mas vêm da linguagem cotidiana. Afora alguns termos psicológicos frequentemente usados como "intuição" e "subconsciente", as palavras não são de maneira nenhuma difíceis de entender, tampouco têm a intenção de estabelecer um jargão profissional. Essa simplicidade é importante, diz ele, porque atuar, essencialmente uma arte e não uma ciência, deve ter um vocabulário prático e concreto que recorra não ao intelecto, mas ao "coração" (versão russa, p.14).

O Método sem dúvida pareceu inverter esse propósito. Como Robert Lewis

\footnotetext{
${ }^{45}$ (NT) "Construindo uma personagem". Tal versão inglesa foi traduzida para o português como "A construção da personagem”, por Pontes de Paula Lima e publicada pela editora Civilização Brasileira. Ver tabela 2 de correlações entre as obras citadas e algumas de suas traduções, em anexo no final do artigo.

${ }^{46}$ (NT) Há aqui um equívoco em relação à data de publicação da parte II de Rabota aktiora nad soboi que, na verdade, não se deu juntamente à primeira parte em 1938, mas sim dez anos depois, em 1948. Sendo assim, a versão inglesa (Building a Character) na realidade foi publicada um ano depois de seu original russo correspondente. "A primeira edição russa do livro O trabalho do ator sobre si mesmo. Parte 2: O trabalho sobre si mesmo no processo criador da encarnação foi publicada em 1948, e os organizadores do volume (Kira Alekséieva, filha de Stanislávski, Tatiana Dorókhina e Geórgui Krísti) decidiram acrescentar ao título "Os materiais para o livro”. Edições posteriores incluíram vários trechos e capítulos, mas só a de 1948 contém apenas aquilo que com toda certeza o autor havia deixado explicitamente para este volume. IN: Elena vássina; Labaki Aimar. Stanislávski: vida, obra e sistema. 1. ed. Rio de Janeiro: Funarte, 2016, p.92.
} 
explicou em suas palestras: "Outra fantasia que foi feita a partir do Método em alguns setores é a da terminologia. Criou-se uma espécie de dogma a partir do qual deveria haver um princípio libertador."47 Um jargão especializado, de fato, se desenvolveu em torno do Método, separando os atores que seguiam o Método, daqueles que não o seguiam. Se, por um lado, a tradução inglesa não criou esse jargão, ela deu o tom para o seu estabelecimento. O exemplo mais dramático desse tom é a tradução que Hapgood faz de "objetivo"48 à palavra zadátcha. Essa palavra russa é muito elementar, geralmente usada no dia a dia e, como sugerido acima, significa "problema", como em um problema aritmético. Stanislávski na verdade utiliza essa associação com a aritmética no texto russo para elucidar sua ideia (versão russa, p. 244). Tal "problema” naturalmente requer uma solução lógica e para o ator, segundo Stanislávski, a solução reside na ação. A palavra russa também é frequentemente traduzida como "tarefa". Nessa interpretação de zadátcha o foco também está em uma ação implícita, já que alguém "desempenha"49 uma tarefa. Ao escolher traduzir a palavra como "objetivo", todavia, Hapgood muda o sentido do conceito de Stanislávski. Webster define "objetivo" como "algo para o qual se aponta ou pelo qual se luta", resumindo, uma meta. Sendo assim, parece que "objetivo" se encontra no polo oposto ao do sentido da palavra zadátcha, não mais fazendo referência a uma ação, mas sim ao resultado da ação. Quando Stanislávski deseja discutir o resultado ao invés das circunstâncias que impulsionam uma ação, ele geralmente usa o termo russo para meta, tsel' 50 (versão russa, p.91). Além disso, mesmo que seja uma palavra padrão da língua inglesa, objective é mais obscura e menos comumente usada, em inglês, do que a palavra russa zadátcha, sobretudo quando utilizada no contexto do processo que parte de um "problema" até uma "ação", descrito por Stanislávski. Em suma, "objetivo" pode facilmente virar um termo profissional - como aconteceu —, claro àqueles que o utilizam e, ligeiramente, misterioso à população

${ }^{47}$ (NA) Robert Lewis. Method or Madness, Nova York: Samuel French, 1958, p.69.

48 (NT) No original "objective": objetivo, meta, finalidade, propósito, alvo.

49 (NT) No original "performs", as aspas são da autora. A pluralidade semântica do verbo "perform", especialmente no que tange ao campo teatral, merece o comentário de que se poderia também o traduzir como "representa", "interpreta", "atua", "executa", "performa".

50 (NT) Tsel' (цтель): “alvo”, “objetivo”, “propósito”. In: Reinaldo Guarino. Dicionário bilíngue Português-Russo. 1. ed. São Paulo: Pomnite Books, 2019. 
em geral.

No teatro norte-americano, uma consequência da tradução feita por Hapgood de zadátcha foi uma identificação do "objetivo" com "ação", devido à mudança de foco inferida na escolha. Mesmo Robert Lewis, em sua clássica tentativa de corrigir a confusão entre o Método e o Sistema, escreve: “Esta palavra 'Ação' como usada aqui, em 1934, foi o termo empregado pelo Group Theatre, também. (É claro que significava ação interior - não ação física). Se você leu os livros, você sabe que foi traduzida pela Sra. Hapgood como ‘Objetivo'”. ${ }^{51}$ Mas, esse não é, de modo algum, o caso. "Objetivo" nitidamente traduz a palavra zadátcha e não deistvie ("ação") 52 . Novamente se vê aqui a comum má compreensão estadunidense do texto, mencionada acima em conexão com o projeto editorial e, agora também, amparada na escolha de palavras.

Tomados em conjunto, os conceitos de "problema" (zadátcha) e "ação" (deistvie) englobam o coração do sistema de Stanislávski, portanto, é importante traçar uma distinção entre as duas ideias. Ao definir o problema, que se origina nas circunstâncias da peça, o ator descobre de forma lógica a sua ação. Ao voltar sua atenção nas ações, o ator ganha foco e confiança em cena. Reportando-se de volta a Aristóteles, Stanislávski pontua que a ação distingue o drama de outras formas de arte e, na edição russa, para reforçar essa ideia, ele rastreia a origem da palavra "drama" (cognatas em russo e inglês) ${ }^{53}$ na palavra grega dran ("fazer"). Ele em seguida utiliza a palavra grega como exemplo à sua escolha por deistvie, derivação da raiz do verbo "fazer" em russo, para descrever seu conceito de "ação" (versão russa, p. 81). Infelizmente essa passagem não está incluída na versão inglesa. ${ }^{54}$

Deistvie é um termo dentre uma entrelaçada sequência de palavras russas

51 (NA) Lewis, 1958, p.29.

52 (NT) Deistvie (действие): “ação”, “efeito”, “funcionamento”, “operação”. In: Reinaldo Guarino. Dicionário bilíngue Português-Russo. 1. ed. São Paulo: Pomnite Books, 2019.

53 (NT) Bem como em português.

54 (NA) Francis Fergusson em seu "Apêndice" a The ldea of a Theatre (Garden City: Doubleday \& Co., 1949), p.253, escreve: "Eu não consigo descobrir se Stanislávski e Nemiróvitch-Dántchenko obtiveram seu conceito de ação a partir de Aristóteles ou não." Essa passagem russa que foi removida oferece a evidência que buscava Fergusson. 
com as quais Stanislávski expressa várias nuances contidas no conceito básico de "ação". Quanto mais claras as distinções entre essas palavras, mais clara emerge a "ação", enquanto um conceito concreto. As principais diferenças que Stanislávski faz são as seguintes: ele distingue a palavra igrát ("representar"55 e geralmente traduzida como "atuar"56) da palavra russa delát e deistvovat ("fazer" e "agir"57). ${ }^{58}$ Ele desconsidera a primeira palavra mais frequentemente usada para atuação, pois ela sugere fingimento. Stanislávski afirma que para atuar, a pessoa deve fazer algo como se aquilo fosse real, deve-se agir sobre o palco e não representar. A palavra para "ação" (deistvie) deriva das raízes dessas duas últimas palavras, não da primeira. A partir dessa derivação pode-se facilmente entender a insistência de Stanislávski de que o ator use um verbo ativo para descrever sua "ação", pois esta representa sempre aquilo que o ator faz em cena para poder solucionar seus problemas. Posteriormente Stanislávski distingue deistvie do vocábulo russo mais abstrato aktívnost"59 ou "o estado de se estar em ação". Essa palavra descreve atividades gerais sobre o palco se comparada com deistvie, esta, por sua vez, é uma ação que contém em si uma motivação baseada na solução intentada diante de um problema específico. Stanislávski dá inúmeros exemplos dessa distinção. Meramente abrir uma porta é aktívnost, enquanto abrir uma porta para ver se um louco se encontra atrás dela é deistvie. Sentar-se no palco só por sentar-se é aktívnost, agora sentar-se sobre o palco a fim de aguardar por uma instrução é uma ação (versão russa, p.80-81).

Como em inglês não há um sistema linguístico de raízes parecidas, qualquer tradutor acharia impossível fazer todas essas distinções de forma clara apenas

55 (NT) No original: "to play", pode nesse contexto também ser traduzida como "interpretar" e "atuar", porém, a palavra possui outras possibilidades semânticas, sendo algumas delas "jogar", "desempenhar", "brincar", "tocar" e "executar".

56 (NT) No original: "to act", que também pode ser traduzido por "agir", "representar", "interpretar", "fazer”, "intervir", "proceder."

57 (NT) No original: "to do and to behave", em que "to do" pode ser traduzido também como executar ou desenvolver e "to behave", por sua vez, como "comportar-se".

58 (NT) lgrát (играть): "tocar", "desempenhar (teatr.)", "jogar”, "brincar”; delát (делать): “fazer”; deistvovat (действовать): “atuar", "agir". In: Reinaldo Guarino. Dicionário bilíngue Português-Russo. 1. ed. São Paulo: Pomnite Books, 2019.

59 (NT) Aktívnost (активность): “atividade”. In: Reinaldo Guarino. Dicionário bilingue Português-Russo. 1. ed. São Paulo: Pomnite Books, 2019 
através da escolha de palavras. A inconsistência do emprego feito por Hapgood, no entanto, confunde a questão mais do que seria necessário. Tomemos como exemplo a seguinte passagem: o diálogo envolve um exercício em que uma atriz foi convidada a sentar-se no palco e aguardar as próximas instruções do seu professor. Contudo, antes de dar quaisquer orientações, o professor declara o exercício encerrado com êxito, para a surpresa da atriz que sente que não havia feito nada. As palavras russas e uma escolha consistente das suas correlatas em inglês estão em colchetes para fins de comparação. ${ }^{60}$

- Como vocês se sentem? - perguntou o Diretor enquanto eles voltavam aos seus lugares no auditório.

- Eu? Por quê? Nós atuamos [igrát / act]?

- Claro que sim.

- Nossa! Mas eu pensei... Eu só estava sentada e aguardando você encontrar seu lugar nos livros e me dizer o que fazer [delát / do]. Como assim, eu não atuei [igrát / act] nada.

Então ele se virou ao restante de nós. - O que chamou a atenção de vocês como o mais interessante? - ele perguntou. - Sentar-se sobre o palco e exibir seus pezinhos, como fez Sonia, ou o corpo inteiro, como Grisha, ou sentar-se com uma finalidade específica [delát / in order to do] ainda que tão simples quanto esperar que algo aconteça? Pode ser que não haja nisso um interesse particular em si, mas é a vida, ao passo que se exibir te joga para fora do domínio da arte viva.

- No palco você deve estar sempre representando algo [deistvovat / behaving]; ação [deistvie / action], movimento [aktívnost / the state of being in action] é a base para a arte do ator. [Aqui foi suprimida a passagem sobre a etimologia da palavra “drama."]

- Mas - rompeu Grisha -, você acabou de dizer que é necessário atuar [deistvovat / behaving] e que exibir os pés ou a si próprio, como eu fiz, não é ação.

60 (NT) Nessa passagem a autora Sharon M. Carnicke transcreve ipsis litteris um trecho da tradução inglesa de Elizabeth Hapgood, An Actor Prepares, fazendo apenas inferências entre colchetes. Desse modo, optei por manter os colchetes da autora como no artigo original, apenas sublinhando na tradução da transcrição os termos aos quais os colchetes da autora fazem referência. Para uma melhor compreensão da análise terminológica e das propostas de termos sugeridas por ela, ver a tabela 1, em anexo. 
[Nenhuma palavra direta é traduzida aqui, isso é uma paráfrase de uma frase da página anterior na edição russa]. Por que se sentar em uma cadeira, como você fez, é uma ação [deistvie / action], mesmo sem mover um dedo? Para mim pareceu uma completa falta de ação [bezdeistvie / inaction]...

- Você pode sentar-se sem um movimento e ao mesmo tempo estar em completa ação [deistvovat / behave]. Tampouco isso é tudo. Frequentemente, a imobilidade física é o resultado direto da intensidade interna [deistvie / action].

- Sobre o palco é necessário atuar [deistvovat / to behave] seja de dentro para fora, seja de fora para dentro. ${ }^{61}$

[versão inglesa, p.34-35; versão russa, p.81]

Desconsiderando-se as supressões feitas da versão russa e as variações sintáticas, nota-se facilmente o quão inconsistente é o emprego feito por Hapgood, através da comparação das suas escolhas em inglês com as palavras russas. Se por um lado ela inicialmente estabelece uma clara distinção entre igrát ("atuar") ${ }^{62}$ e deistvovat (representar) 63 , aproveitando-se bem do sistema linguístico de raiz inglesa, por outro ela não mantém essas escolhas ao longo do trecho. A distinção entre os termos fica completamente perdida ao fim da passagem quando ela traduz deistvovat pela palavra "atuar" ${ }^{4}$, eliminando com isso a distinção inicial que ela havia feito entre "atuar" e "agir". Em inglês, portanto, a passagem sugere uma conclusão absurda: a principal coisa a se fazer no palco não é atuar, senão atuar. A obra russa conduz à conclusão mais lógica: o principal não é atuar, mas agir.

Com semelhante inconsistência, Hapgood não retoma sua escolha inicial para deistvovat ("representar") na pergunta de Grisha. ${ }^{65}$ Ela, de novo, substitui a palavra

${ }^{61}$ (NA) O nome Grisha, por acaso, é um apelido masculino em russo. Na verdade, todos os nomes dos alunos na versão inglesa são apelidos, enquanto a versão russa usa apenas os nomes completos e formais, dos alunos. Essa decisão também altera o tom do trabalho em inglês, fazendo os alunos parecerem mais jovens, menos experientes e, até mesmo, menos sérios.

\footnotetext{
62 (NT) Números 1 e 3 na transcrição comparativa da tabela 1, em anexo.

63 (NT) Número 5 na transcrição comparativa da tabela 1, em anexo.

${ }^{64}$ (NT) Número 13 na transcrição comparativa da tabela 1, em anexo.

65 (NT) Número 8 na transcrição comparativa da tabela 1, em anexo.
} 
por "atuar". Em russo, o aluno visivelmente pede ao professor por uma elucidação dos termos, repetindo cuidadosamente as palavras de seu professor, mas em inglês, como Grisha não repete os termos anteriormente usados pelo professor, ele parece ser ou desatento ou não muito inteligente. Em russo, sua pergunta está longe de ser retórica.

Por fim, Hapgood às vezes traduz deistvie ("ação") por um conceito totalmente diferente, como ela faz no trecho acima quando ela nos traduz deistvie como "intensidade interna". ${ }^{66}$ Essa escolha, outra vez colocando a ênfase sobre o trabalho emocional do ator, está incorreta do ponto de vista da teoria. A intensidade ou o conteúdo emocional da cena, como explica Stanislávski, é o resultado da ação e não a ação em si. De forma semelhante, no começo do livro, Hapgood usa a palavra "ação" para traduzir um outro conceito envolvendo emoções. Um aluno, tentando recordar-se de uma cena que ele acabou de improvisar, constata: "Acho que me lembro das minhas ações" (versão inglesa, p.12; versão russa, p.46). Aqui "ações" é usado para traduzir o termo russo ochtchuchtchénie ${ }^{67}$, mais comumente traduzido como "sensações". A distinção entre a vida emocional e a "ação" fica, mais uma vez, nebulosa. Stanislávski tenta nos fazer entender com esse incidente que o aluno não pode se lembrar do que ele fez no palco, apenas do que ele sentiu, provando com isso que ele havia focado sua atenção de maneira incorreta em seu trabalho. Se esse aluno tivesse de fato relembrado suas ações, ele não precisaria do mestre. A lógica clara do texto russo fica outra vez confusa, em inglês. Enfim, a inconsistência terminológica apaga distinções específicas feitas em russo, tornando difícil detectar a lógica do argumento de Stanislávski. Esse fato é irônico, dada a própria insistência de Stanislávski na criação de ações de maneira lógica mediante as circunstâncias da peça.

Por meio desses poucos exemplos eu aponto algumas das principais diferenças entre as duas versões dos livros de Stanislávski e como tais diferenças afetam as interpretações do Sistema. Outros exemplos podem ser encontrados,

${ }^{66}$ (NT) Número 12 na transcrição comparativa da tabela 1, em anexo.

${ }^{67}$ (NT) Ochtchuchtchénie (ощущение): “sensação”. In: Reinaldo Guarino. Dicionário bilíngue Português-Russo. 1. ed. São Paulo: Pomnite Books, 2019. 
mas só levariam a conclusões parecidas: remoções prejudicam a lógica do texto e algumas vezes alteram a ênfase geral ou o foco de um trecho; a tradução inconsistente do vocabulário ou escolhas de palavras imprecisas confundem a diferenciação entre ideias similares, porém diferentes e, às vezes, até desorientam a lógica natural do trecho.

Tentei também indicar o valor dessa comparação tanto para a comunidade acadêmica, quanto para os atores. Pesquisadores podem descobrir que o método tardio das ações físicas de Stanislávski foi o resultado mais lógico das suas primeiras ideias sobre ação, do que hoje é óbvio. Atores podem encontrar utilidade na lógica simples e na terminologia fácil da versão russa. Por último, ambos poderão reavaliar a originalidade dos grandes professores estadunidenses e suas reformulações das ideias de Stanislávski, à luz desses problemas de tradução.

Infelizmente as leis de direitos autorais não autorizam uma nova tradução dos livros de Stanislávski para o futuro próximo, a qual poderia incorporar essas questões na estrutura da obra. ${ }^{68}$ Ainda assim, a relevância da supressão de passagens e da inconsistente escolha de palavras não devem ser negligenciadas, quando a oportuna tarefa de se reavaliar a obra de Stanislávski começar. Acadêmicos devem ter em mente o quanto a história da publicação e do processo editorial de seus livros comprometem uma adequada compreensão de todas as suas teorias sobre teatro.

\section{Referências}

BENEDETTI, Jean. Stanislavski: An Introduction. Nova York: Theatre Arts Books, 1982.

CLURMAN, Harold. The Fervent Years. Nova York: Hill \& Wang, 1957.

EDWARDS, Christine. The Stanislavsky Heritage: Its Contribution to the Russian and American Theatre. Nova York: New York University Press, 1965.

68 (NT) O presente artigo data de 1984 e, já tendo findado aquele cenário dos direitos autorais de Hapgood sobre a obra de Stanislávski, pouco mais de duas décadas depois, em 2008, a tradução de Jean Benedetti de Rabota aktiora nad soboi foi publicada como An Actor's Work: a student's diary (O trabalho do ator: o diário de um aluno). Do mesmo tradutor, em 2010, a editora Routledge também publicou a tradução de Rabota aktiora nad rol'iu, sob o título An Actor's Work on a Role (O trabalho de um ator sobre o papel). 
EMELJANOW, Victor (org.). Chekhov: The Critical Heritage. Boston: Routledge \& Kegan Paul, 1981.

FERGUSSON, Francis. The Idea of a Theatre. Garden City: Doubleday \& Co., 1949.

GUREVITCH, Liubov lákovlevna. "Istoria Severnogo vestnika”, Russkaia literatura XX veka. (ed.) VENGEROV, S. A. Munique: Wilhem Fink Verlag, 1972.

LEWIS, Robert. Method or Madness. Nova York: Samuel French, 1958.

MACGREGOR, Robert M. Further Entries for a Chronology. In: MUNK, Erica (org.). Stanislavsky and America. Nova York: Hill and Wang, 1966.

MAGARSHACK, David. Introduction. In: Stanislavsky on the Art of the Stage. Boston: Faber \& Faber, 1950.

SENELICK, Laurence. Stanislavsky's Double Life in Art. Theatre Survey, v. 22, n. 2, Nov., 1981.

STANISLÁVSKI, Constantin. An Actor Prepares. Trad. Elizabeth Reynolds Hapggod. Nova York: Theatre Arts Books, 1936.

STANISLÁVSKI, Constantin. Building a Character. Trad. Elizabeth Reynolds Hapggod. Nova York: Theatre Arts Books, 1949.

STANISLÁVSKI, Constantin. Creating a Hole. Nova York: Theatre Arts Books, 1961.

STANISLÁVSKI, Constantin. Creating a Role. Trad. Elizabeth Reynolds Hapggod. Nova York: Theatre Arts Books, 1961.

STANISLÁVSKI, Constantin. My Life in Art. Trad. J. J. Robbins. Boston: Little, Brown \& Co., 1924.

STANISLÁVSKI, Constantin. Rabota aktiora nad soboi, Tchast I. Moscou, 1938.

STANISLÁVSKI, Konstantin. Moiá Jizn’v Iskússtve. Moscou, 1926.

STANISLÁVSKI, Konstantin. Rabota aktiora nad rol'iu. Moscou, 1957.

STANISLÁVSKI, Konstantin. Rabota aktiora nad soboi, Tchast I. Moscou, 1938.

STANISLÁVSKI, Konstantin. Rabota aktiora nad soboi, Tchast I/. Moscou, 1948.

STANISLÁVSKI, Konstantin. Sobránie Sotchinéni. Moscou, 1961, v. VIII.

TOPORKOV, vassíli. K. S. Stanislávski na repetítsi. Moscou, 1950.

TOPORKOV, Vassíli. Stanislavski in Rehearsal: The Final Years. Trad. Christine Edwards. Nova York: Theatre Arts Books, 1979. 
An Actor Prepares e Rabota aktiora nad soboi, Tchast I: Uma comparação entre o Stanislávski inglês e o russo Sharon Marie Carnicke I Tradução: Felipe Rodrigues Carvalho

VINOGRÁDSKAIA, Irina. Jizn' i tvortchestva K. S. Stanislavskogo: Lietopis'. Moscou, 1973.

Recebido em: 18/10/2021

Aprovado em: 18/10/2021

Universidade do Estado de Santa Catarina - UDESC

Programa de Pós-Graduação em Teatro - PPGT

Centro de Arte - CEART

Urdimento - Revista de Estudos em Artes Cênicas

Urdimento.ceart@udesc.br 


\begin{tabular}{|c|c|c|c|c|c|}
\hline \multicolumn{2}{|l|}{$\begin{array}{l}\text { STANISLÁVSKI, K. S. AN ACTOR PREPARES (trad. ELIZABETH } \\
\text { HAPGOOD) }\end{array}$} & $\begin{array}{l}\text { EM INGLÊS, NA TRADUÇÃO } \\
\text { ORIGINAL DE AN ACTOR } \\
\text { PREPARES DE ELIZABETH R. } \\
\text { HAPGOOD }\end{array}$ & $\begin{array}{l}\text { NO ORIGINAL } \\
\text { EM RUSSO }\end{array}$ & $\begin{array}{l}\text { TERMOS } \\
\text { SUGERIDOS POR } \\
\text { SHARON M. } \\
\text { CARNICKE } \\
\end{array}$ & $\begin{array}{l}\text { TRADUÇÃO A PARTIR DOS } \\
\text { TERMOS PROPOSTOS POR } \\
\text { SHARON M. CARNICKE }\end{array}$ \\
\hline \multirow{4}{*}{$\begin{array}{l}\text { - Como vocês se sentem? - perguntou o Diretor enquanto eles } \\
\text { voltavam aos seus lugares no auditório. } \\
\text { - Eu? Por quê? Nós atuamos } \\
\text { - Claro que sim. } \\
\text { - Nossa! Mas eu pensei... Eu só estava sentada e aguardando } \\
\text { você encontrar seu lugar nos livros e me dizer o que fazer }{ }^{2} \text {. Como } \\
\text { assim, eu não atueín nada. } \\
\text { Então ele se virou ao restante de nós. - O que chamou a } \\
\text { atenção de vocês como o mais interessante? - ele perguntou. }\end{array}$} & 1 & Did we act? & играть (igrát) & act ("atuar") & Nós atuamos? \\
\hline & 2 & (...) and would tell me what to do. & делать (delát) & do ("fazer") & fazer. \\
\hline & 3 & Why, I didn't act anything. & играть (igrát) & act ("atuar") & \\
\hline & 4 & $\begin{array}{l}\text { (...) like Grisha } \\
\text { specific purpos } \\
\text { one as waiting }\end{array}$ & делать (delát) & & $\begin{array}{l}\text { sentar-se } \\
\text { inda que } \\
\text { sperar }\end{array}$ \\
\hline \multirow{3}{*}{$\begin{array}{l}\text { ou o corpo inteiro, como Grisha, ou sentar-se com uma finalidade } \\
\text { específica }{ }^{4} \text { ainda que tão simples quanto esperar que algo } \\
\text { aconteça? Pode ser que não haja nisso um interesse particular em } \\
\text { si, mas é a vida, ao passo que se exibir te joga para fora do } \\
\text { domínio da arte viva. }\end{array}$} & \multirow{3}{*}{$\begin{array}{l}5 \\
6 \\
7\end{array}$} & \multirow{3}{*}{$\begin{array}{l}\text { On the stage, you must always be } \\
\text { enacting } \\
\text { motion }^{7} \text { something; action } \\
\text { actor. }\end{array}$} & & & \multirow{3}{*}{ 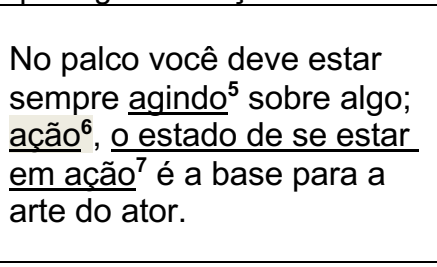 } \\
\hline & & & & action (“ação") & \\
\hline & & & $\begin{array}{l}7 \text { активность } \\
\text { (aktívnost) }\end{array}$ & & \\
\hline \multirow{6}{*}{ 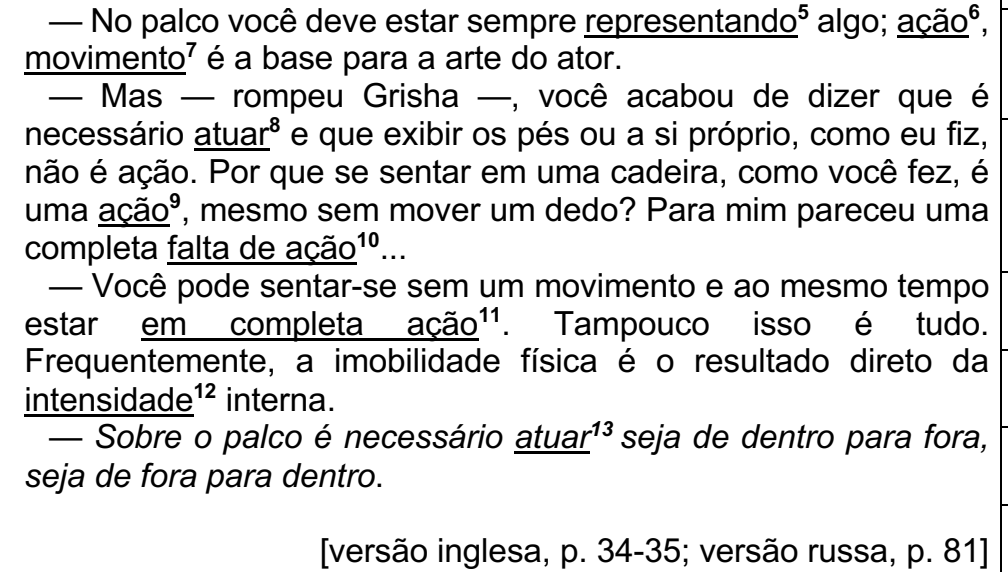 } & 8 & $\begin{array}{l}\text { (...) you have just said that acting is } \\
\text { necessary }(\ldots) \text {. }\end{array}$ & & behaving (“agir") & $\begin{array}{l}\text { (...) você acabou de dizer } \\
\text { que é necessário agir }(\ldots)\end{array}$ \\
\hline & 9 & $\begin{array}{l}\text { Why is it action to sit in a chair, as } \\
\text { you did, without moving a finger? }\end{array}$ & $\begin{array}{l}\text { действие } \\
\text { (deistvie) }\end{array}$ & action (“ação") & $\begin{array}{l}\text { Por que se sentar em uma } \\
\text { cadeira, como você fez, é } \\
\text { uma ação, mesmo sem } \\
\text { mover um dedo? }\end{array}$ \\
\hline & 0 & lete lack & $\begin{array}{l}\text { бeз } \\
\text { (bez }\end{array}$ & inaction ("inação") & $\begin{array}{l}\text { (...) para mim pareceu uma } \\
\text { completa inação... }\end{array}$ \\
\hline & & $\begin{array}{l}\text { (...) and at the same time be in full } \\
\text { action. }\end{array}$ & & behave ("agindo") & $\begin{array}{l}\text { (...) e ao mesmo tempo estar } \\
\text { agindo. }\end{array}$ \\
\hline & 12 & $\begin{array}{l}\text { (...) the direct result of inner } \\
\text { intensity. }\end{array}$ & & action (“ação") & $\begin{array}{l}\text { (...) o resultado direto da } \\
\text { ação interna. }\end{array}$ \\
\hline & 13 & $\begin{array}{l}\text { On the stage it is necessary to act, } \\
\text { either outwardly or inwardly. }\end{array}$ & & to behave ("agir") & $\begin{array}{l}\text { Sobre o palco é necessário } \\
\text { agir (...). }\end{array}$ \\
\hline
\end{tabular}

*Em cinza estão os trechos em que Sharon M. Carnicke corrobora com a escolha terminológica da tradução de Elizabeth Hapgood e não sugere outro termo. 
Tabela 2. Correlação entre as obras de Stanislávski citadas e suas respectivas publicações em português e inglês

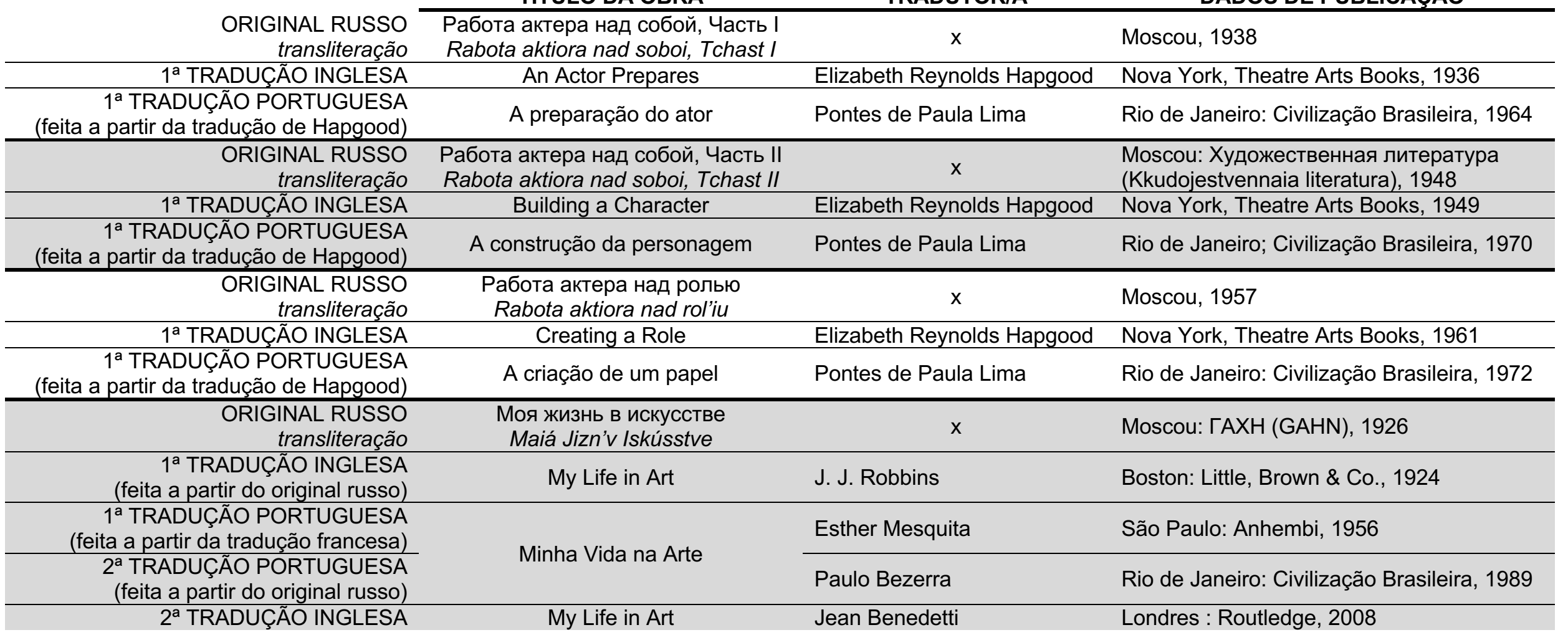

